Plemyannikov M.,
Kornilovych B.

\title{
PREPARATION OF A SELF-CLEANING GLASS USING SOLUTIONS OF TITANIUM FLUOR COMPLEXES
}

Об’єктом дослідження є силікатне скло з наноструктурованним покриттям з оксиду титану (в модифікації анатаза), яке відзначається фотокаталітичною активністю $i$, як наслідок, набуває здатність до самоочищення в умовах ультрафіолетового опромінювання.Існуючий промисловий метод нанесення такого покриття здійснюється піролітичним способом, але він ефективний для великомасштабного виробництва, і здійснюється для великогабаритних виробів з листового флоат-скла. Для виробництва малосерійних, або поштучних виробів, він не виправданий. Це стосується виробів складної конфігурачїі, $i$, особливо, порожнистих. У нагоді постають методи нанесення покриттів з рідкої фази. В першу чергу - золь-гель методом. Класичний такий метод потребує в якості прекурсорів алкоксиди титану, які мають високу вартість.

Більш дешевим і гнучким є метод нанесення покриття з розчинів титанфторкомплексних сполук. Як прекурсор використовується гексафтортитанат амонію, але він дорогий. Запропоновано видозмінити ланцюг хімічних перетворень, а саме: в якості первинних прекурсорів використовувати такі, що є більш дешеві і доступні. Запропоновано його одержувати штучним шляхом, - біфторидним способом.

В ході дослідження використовувалися біфторид амонію $\mathrm{NH}_{4} \mathrm{HF}_{2}$ і оксид титану $\mathrm{TiO}_{2}$, які за запропонованим методом синтезу утворюють $\left(\mathrm{NH}_{4}\right)_{2} \mathrm{TiF}_{6}$, його поява підтверджена рентгенофазовим аналізом.

Фторування оксиду титану біфторидом амонію відбувалося при температурі, що не перевищує $200^{\circ} \mathrm{C}$. Фторування супроводжувалося виділенням тільки парів води й аміаку.

Отримано фотокаталітичне покриття на зразках флоат-скла шляхом осадження кристалічної фази анатаза з водного розчину $\left(\mathrm{NH}_{4}\right)_{2} \mathrm{TiF}_{6}$. Наявність анатаза підтверджена рентгенофазовим аналізом. Розмір кристалічних утворень не перевищує 15-20 нм. Здатність до самоочищення оцінюється тестом на гідрофільність скла і спектральними характеристиками покриття в ультрафіолетовому діапазоні.

Завдяки цьому забезпечується можливість отримання самоочисного покриття на склі, яке, у порівнянні з аналогічними відомими, не поступається за якістю і має такі переваги: дешевизна і доступність, відсутність шкідливих викидів, що відповідає принщипам «зеленої хімї».

Ключові слова:силікатне скло, наноструктуроване покриття, самоочисне покриття, $\left(\mathrm{NH}_{4}\right)_{2} \mathrm{TiF}_{6}$, рентгенофазовий аналіз, біфторидний спосіб.

Received date: 25.06 .2019

Accepted date: 11.07.2019

Published date: 31.10 .2019
Copyright (C) 2019, Plemyannikov M., Kornilovych B. This is an open access article under the CC BY license (http://creativecommons.org/licenses/by/4.0)

\section{Introduction}

Glass, due to its transparency, is a unique material of modern materials science. However, not all indicators of the properties of glass and products from it remain at the desired level. They can be quite easily improved by surface modification. In this case, the surface layer itself is modified either chemically or physically to a very shallow depth from a few nanometers (nanotechnology) to several micrometers. The incorporation of certain substances nanoclusters into the surface layer of glass causes the emergence of new extreme properties of the glass product. First of all, the appearance of properties associated with quantum optical phenomena. One such extreme modifier is titanium dioxide.

A contemporary urgent scientific problem is the creation of self-cleaning coatings on glass [1]. Glass is self-cleaning or easy to clean with minimal human intervention, which significantly reduces maintenance costs. Currently, several methods for the manufacture of such coatings are known [2].
The main cause of glazing contamination is atmospheric aerosols. They get into the atmosphere as a result of natural processes (erosion, volcanic eruptions, fires), or as a result of human activities (motor vehicles, industrial fuel plants, bitumen, asphalt preparation, garbage burning, cigarette smoke, cooking, especially frying meat). The phenomenon of photoinduced hydrophilicity, discovered in 1997, marked the beginning of the creation of nanostructured transparent coatings for glasses based on titanium dioxide, which exhibit self-cleaning properties under the influence of ultraviolet radiation (UV radiation).

\section{The object of research and its technological audit}

The object of research is silicate glass with a nanostructured coating of titanium oxide (in the anatase modification), which is noted for photocatalytic activity and, as a result, acquires the ability to self-clean under ultraviolet irradiation. 
Titanium dioxide $\left(\mathrm{TiO}_{2}\right)$, in the modification of anatase, has been used as a highly active photocatalytic material and has received great attention in the scientific community over the past two decades [3].

Nanostructured titanium dioxide has a unique photocatalytic property. Its essence lies in the fact that in the volume of a semiconductor particle under the influence of electromagnetic radiation from the UV range of the generated electron -hole pairs, which, when $\mathrm{TiO}_{2}$ particles reach the surface, enter into redox reactions with molecules adsorbed on it.

Titanium dioxide is an n-type semiconductor. The band gap for anatase and rutile is $3.2 \mathrm{eV}$ and $3.0 \mathrm{eV}$, respectively [4]. Photocatalytic reactions are initiated when photons are absorbed with energy equal to or greater than the band gap. This leads to the transition of an electron from the semiconductor valence band to the conduction band with the formation of an electron-hole pair. The highest catalytic activity in such processes is expressed by the anatase modification. The optimal particle size of $\mathrm{TiO}_{2}$ for catalytic processes lies in the range from 15 to $110 \mathrm{~nm}$.

Titanium dioxide is used to create gas sensors [5], in medicine as biocompatible and antibacterial coatings [6]. It acts as a catalyst in the processes of oxidation of halogenorganic compounds [7] and reduction of nitrogen oxides [8].

The well-known method of applying a self-cleaning coating based on anatase by pyrolysis from a vapor-gas phase is effective for large-tonnage production of flat glass by the float method. For the production of small-scale, or piece products, products of complex configuration, and especially hollow, it is not advisable. In the case there are methods of coating from the liquid phase. First of all, the sol-gel method. The classical such method requires titanium alkoxides, which are of high cost, as precursors. Cheaper and more flexible is the method of coating from solutions of titanium fluorine complex compounds. Ammonium hexafluorotitanate is used as a precursor, but it is expensive. The paper proposes to modify the chain of chemical transformations, namely: to use the cheaper and more affordable ones as primary precursors. It is proposed to use anatase-based coatings. Since the known method in which $\left(\mathrm{NH}_{4}\right)_{2} \mathrm{TiF}_{6}$ is used as a precursor for liquid-phase deposition is not rational due to the high cost of this substance.

\section{The aim and objectives of research}

The aim of research is development of a new method for preparing precursors for applying an anatase-based nanostructured self-cleaning coating on glass.

To achieve this aim,it is necessary to complete the following objectives:

1. To propose other, less valuable and more affordable precursors for the implementation of the technological process, in the chain of which $\left(\mathrm{NH}_{4}\right)_{2} \mathrm{TiF}_{6}$ becomes an intermediate substance, as well as appropriate laboratory equipment and set the synthesis parameters of $\left(\mathrm{NH}_{4}\right)_{2} \mathrm{TiF}_{6}$.

2. To assess the perfection of the synthesis reactions by the method of X-ray phase analysis of the synthesized substance.

3. To coat silicate glass and make sure that the coating is nanostructured anatase.

4. To ascertain the presence of photocatalytic activity of the glass surface by spectrophotometry of the sample in the UV range and by measuring the contact angle.

\section{Research of existing solutions of the problem}

Today, there are many methods and technologies for producing $\mathrm{TiO}_{2}$ nanoparticles with various morphologies [9]. They obey two main directions: high-temperature synthesis from the gas phase and low-temperature synthesis from the liquid phase.

According to the first direction, the most common is the method of pyrolysis in the gas phase. To obtain $\mathrm{TiO}_{2}$ by high-temperature decomposition, gaseous halides [10] or titanium alcoholates that are volatile at elevated temperatures are used as gaseous precursors. In the presence of water vapor, titanium tetrachloride vapor can be hydrolyzed to form finely dispersed $\mathrm{TiO}_{2}$ nanoparticles [11]. Depending on the processes of formation of $\mathrm{TiO}_{2}$ by chemical reactions, the methods of chemical and physical deposition are distinguished.

An example of chemical vapor deposition is the preparation of $\mathrm{TiO}_{2}$ nanocrystalline films of pyrolysis of titanium (IV) tetraisopropoxide in a gas mixture of helium and oxygen [12]. By physical deposition of titanium metal upon heating in vacuum followed by oxidation with gaseous oxygen, $\mathrm{TiO}_{2}$ crystals can be obtained on the surface of various materials [13].

Low-temperature synthesis from the liquid phase is carried out by various methods, among which the following are most common.

The hydrothermal synthesis method is based on the ability of water and aqueous solutions to dissolve substances that are practically insoluble under normal conditions at high temperature (up to $500{ }^{\circ} \mathrm{C}$ ) and pressure (10-80 MPa). Using the hydrothermal synthesis method, various modifications of $\mathrm{TiO}_{2}$ can be obtained [14].

Solvothermal synthesis is carried out in organic solvents having a higher boiling point. Such a synthesis of $\mathrm{TiO}_{2}$ nanoparticles in nonaqueous media at a higher temperature makes it possible to obtain more dispersed titanium dioxide particles [15].

One of the most popular methods for the preparation of $\mathrm{TiO}_{2}$ nanosized particles is the hydrolysis of titaniumbearing precursors, for example, $\mathrm{TiCl}_{4}$, titanium alkoxides, or titanyl sulfate.

The sol-gel method, widely used for the synthesis of glass and ceramics, has also been adapted to produce various coatings based on nanostructured $\mathrm{TiO}_{2}$. Nanosized $\mathrm{TiO}_{2}$ particles are synthesized by the sol-gel method using hydrolysis of titanium precursors. For the synthesis of $\mathrm{TiO}_{2}$ with titanium alkoxides, the most effective titanium tetraisopropoxide and titanium tetrabutoxide.

The sol-gel method has been successfully used for the manufacture of silica, titanium, or composite (hybrid) coatings [16]. The synthesis technique of $\mathrm{TiO}_{2}$ allows the formation of the anatase phase even at low temperatures [17], especially when titanium tetraisopropoxide is used as alkoxides, and the acid acts as an electrostatic stabilizer and hydrolysis catalyst [18].

The technologies for producing $\mathrm{TiO}_{2}$ nanoparticles obey two principal directions.

The first direction is the production of nanopowders, as such. In the state of lyosols or aerosols, they are used as highly effective cleaners of water or gas environments. The vast majority of scientific papers are devoted to this particular area. 
The second direction is the production of nanocoatings on various materials.

The self-purification phenomenon, which is considered in this work, occurs on the basis of a combination of two effects: the photoinduced properties of a thin film of $\mathrm{TiO}_{2}$, namely: photocatalytic activity leads to degradation of organic substances, superhydrophilicity provides high surface wetness.

The self-cleaning effect of glass occurs with the participation of water (rain, service flushing) [19].

However, atmospheric aerosol pollution is not the only problem. An additional problem is the condensation of moisture, which settles on the cold surface of the glass. Condensation on glass surfaces can be minimized to a certain extent [20]. The combined effect of these two effects eliminates fogging of the glass. A thin transparent film of photoactive $\mathrm{TiO}_{2}$ under the influence of light destroys organic pollutants, the surface is well wetted, and water falling on such a surface does not collect into droplets, but spreads over the surface. And then it evaporates without the appearance of spots and stripes.

On glass, water has a contact angle of wetting, which ranges from 30 to 90 degrees. Nowadays, unknown materials on the surface of which this angle would be less than 10 degrees. And only a titanium dioxide film can achieve such results. On the surface of the film, when it is subjected to ultraviolet radiation, the angle gradually decreases and after 4...24 hours of exposure reaches almost zero degrees. At this stage, a hydrophobic surface becomes completely hydrophilic, and such a surface is called a «super hydrophilic».

Under the influence of light, not only organic molecules are destroyed on the surface of titanium dioxide, but harmful microorganisms, even those that are resistant to ultraviolet light, also die.

\section{Methods of research}

Spectrophotometry of glass samples is carried out using a Unico 2100 UV spectrophotometer (Russia). The operating range is 200 to $1000 \mathrm{~nm}$.

$\mathrm{X}$-ray phase analysis is carried out using a DRON 3M UV diffractometer (Russia). Radiation: $\mathrm{CuK} \alpha . U=30 \mathrm{kV}$. $\Delta 2 \theta=0.05^{\circ}$.

The phases are identified using a JCPDS-ICDD file cabinet.

The calculation of crystallite sizes is carried out according to the Scherrer formula:

$$
L=\frac{A \cdot \lambda_{C u K_{\alpha}}}{\beta \cdot \cos \theta},
$$

where $A$ - the dimensionless form factor (usually taken equal to 0.9$) ; \lambda$ - the wavelength of X-rays; $\beta$ - the peak broa-

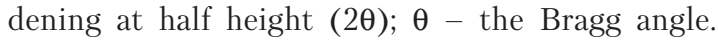

The device for measuring the contact angle - DSA 25 (Germany). Range of measurement is $1-180^{\circ}$. Accuracy $0.1^{\circ}$.

\section{Research results}

The process of liquid phasedeposition is used. It is carried out in an aqueous solution. The method of deposition of thin films of titanium oxide from mixed solutions of $\left(\mathrm{NH}_{4}\right)_{2} \mathrm{TiF}_{6}$ and $\mathrm{H}_{3} \mathrm{BO}_{3}$ is known in the literature [21, 22].
The deposition reaction consists in the equilibrium ligand exchange (hydrolysis) of ions of titanium fluorine complex:

$$
\left[\mathrm{TiF}_{6}\right]^{2-}+n \mathrm{H}_{2} \mathrm{O} \leftrightarrow\left[\mathrm{TiF}_{6-n}(\mathrm{OH})_{n}\right]^{2-n}+n \mathrm{HF} .
$$

Reaction (1) shifts to the right if $\mathrm{F}^{-}$ions are bound by boric acid, which readily reacts with $\mathrm{F}^{-}$ions as follows:

$$
\begin{aligned}
& \mathrm{H}_{3} \mathrm{BO}_{3}+\mathrm{HF} \leftrightarrow \mathrm{HBF}(\mathrm{OH})_{3}, \\
& \mathrm{HBF}(\mathrm{OH})_{3}+\mathrm{HF} \leftrightarrow \mathrm{HBF}_{2}(\mathrm{OH})_{2}+\mathrm{H}_{2} \mathrm{O}, \\
& \mathrm{HBF}_{2}(\mathrm{OH})_{2}+\mathrm{HF} \leftrightarrow \mathrm{HBF}_{3}(\mathrm{OH})+\mathrm{H}_{2} \mathrm{O}, \\
& \mathrm{HBF}_{3}(\mathrm{OH})+\mathrm{HF} \leftrightarrow \mathrm{HBF}_{4}+\mathrm{H}_{2} \mathrm{O} .
\end{aligned}
$$

At the same time, the $\mathrm{F}^{-}$ions in $\left[\mathrm{TiF}_{6}\right]^{2-}$ are gradually replaced by $\mathrm{OH}^{-}$ions. Finally, $\left[\mathrm{TiF}_{6}\right]^{2-}$ turns into $\left[\mathrm{Ti}(\mathrm{OH})_{6}\right]^{2-}$. So, thin films of titanium oxide are formed on the substrate during dehydration of the $\left[\mathrm{Ti}(\mathrm{OH})_{6}\right]^{2-}$ species formed as a result of the hydrolysis of $\left[\mathrm{TiF}_{6}\right]^{2-}$.

The final equation will take the form:

$$
\begin{aligned}
& 2\left(\mathrm{NH}_{4}\right)_{2} \mathrm{TiF}_{6}+3 \mathrm{H}_{3} \mathrm{BO}_{3}= \\
& =3 \mathrm{HBF}_{4}+2 \mathrm{TiO}_{2}+4 \mathrm{NH}_{3}+5 \mathrm{H}_{2} \mathrm{O} .
\end{aligned}
$$

According to the well-known scheme for the implementation of chemical transformations, the precursor is ammonium hexafluorotitanate, the substance is quite expensive and scarce.

It is proposed in the work to obtain it artificially, using the bifluoride method.

The physicochemical basis of the process of fluorination of ammonium bifluoride is that $\mathrm{TiO}_{2}$, when reacted with $\mathrm{NH}_{4} \mathrm{HF}_{2},\left(\mathrm{NH}_{4}\right)_{2} \mathrm{TiF}_{6}$, which becomes a precursor in the reagent-phase deposition scheme.

Processing of titanium oxide with ammonium bifluoride is easy to do: fluorination occurs at a temperature not exceeding $200{ }^{\circ} \mathrm{C}$, by-products (water and ammonia vapors) do not contain fluoride, ensures the environmental safety of the process.

The interaction of titanium oxide with ammonium bifluoride occurs with the formation of ammonium fluorine or oxofluorotitanates. Fluorination is accompanied by the release of only water vapor and ammonia by reaction:

$$
\mathrm{TiO}_{2}+3 \mathrm{NH}_{4} \mathrm{HF}_{2}=\left(\mathrm{NH}_{4}\right)_{2} \mathrm{TiF}_{6}+\mathrm{NH}_{3}+2 \mathrm{H}_{2} \mathrm{O} \text {. }
$$

The output reagents were solved in an equimolar ratio (1:3), ground and mixed in a porcelain mortar.

To carry out such synthesis, a laboratory unit is assembled (Fig. 1). The unit is a vertical muffle electric furnace, in which there is a fluoroplastic glass with a twisting lid, in the opening of which a return air cooler is inserted, prevents premature removal of water. Ammonia is predominantly released, shifts the equilibrium to the right (work under the hood). The temperature in the furnace cavity is controlled by a chromel-alumel thermocouple (CA-thermocouple). The temperature is maintained at $170 \pm 10{ }^{\circ} \mathrm{C}$. Processing time is $5-6$ hours.

After the end of the process, the reaction products are a semi-dry paste-like mass, well soluble in water. The 
resulting solution is filtered. The filtrate is evaporated and hung. The resulting powder is subsequently used to carry

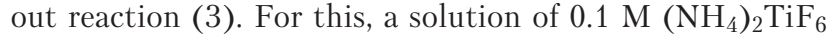
and $0.3 \mathrm{M} \mathrm{H}_{3} \mathrm{BO}_{3}$ is prepared. A glass product (plate) is immersed in the glass and an exposure time of 10 hours is carried out [23-25]. As a result, the glass is covered with a film of titanium oxide.

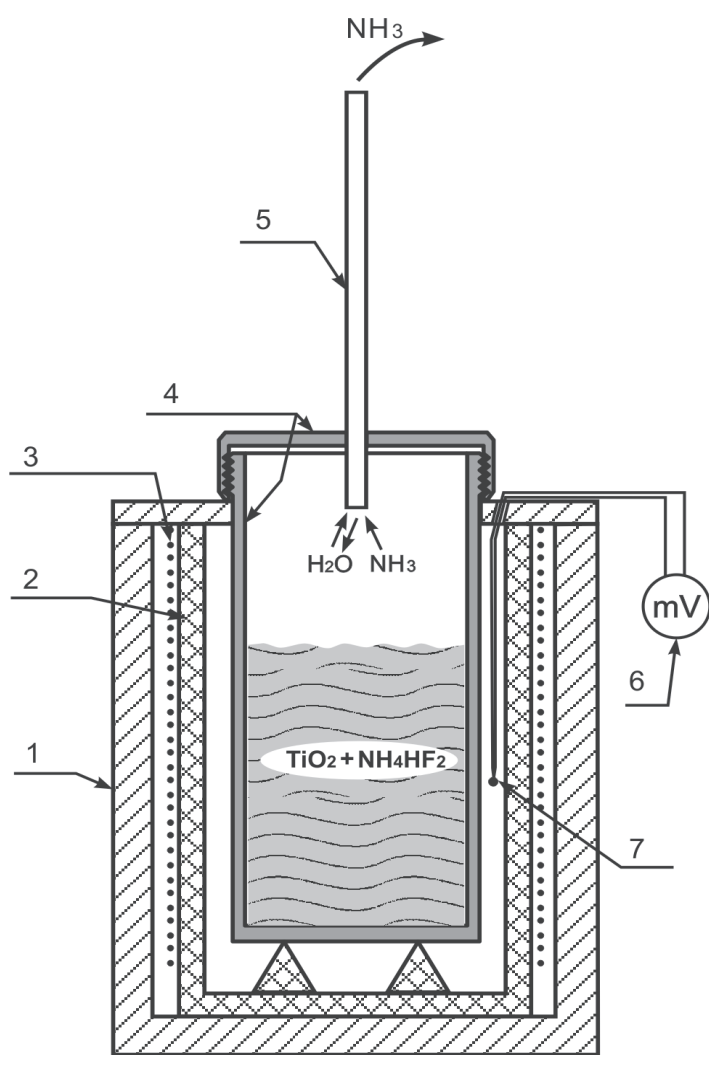

Fig. 1. Scheme of the unit for the synthesis of ammonium hexafluorotitanate: 1 - shaft furnace; 2 - muffle; 3 - heater spiral; 4 - fluoroplastic glass with a lid; 5 - reflux condenser; 6 - measuring device; 7 - CA thermocouple

Fig. 2 shows a diagram of technological operations.

All intermediates and final products are subjected to $\mathrm{X}$-ray phase analysis.

Fig. 3 shows the results of X-ray phase analysis (XRD) of primary titanium oxide, first it is in the modification of rutile and subsequent intermediate solutions.

The results convincingly show the feasibility of the proposed method for producing ammonium hexafluorotitanate (Fig. 3, diffraction patterns 2).

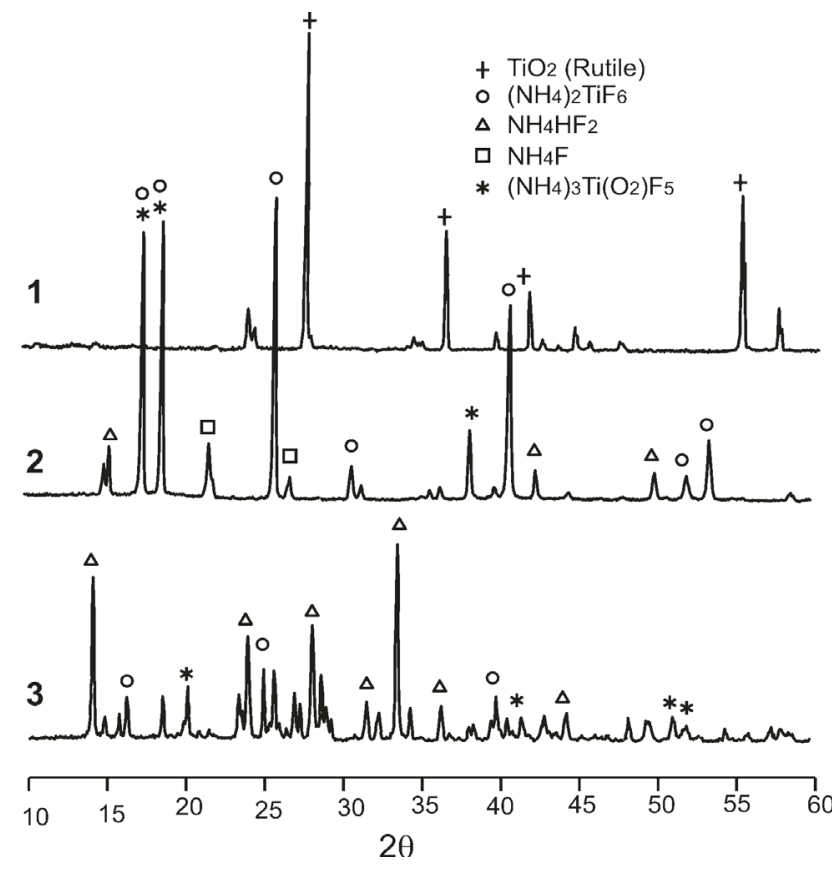

Fig. 3. X-ray phase analysis of the initial powder of titanium oxide and subsequent intermediate substances obtained in solutions: 1 - output titanium dioxide (rutile); 2 - products of its interaction $\mathrm{TiO}_{2}$ with $\left(\mathrm{NH}_{4}\right) \mathrm{HF}_{2} ; 3-$ mother liquor for the anatase deposition

There is an assumption that adverse reactions also occur with the formation of ammonium oxofluorotitanate:

$$
\mathrm{TiO}_{2}+3 \mathrm{NH}_{4} \mathrm{HF}_{2}=\left(\mathrm{NH}_{4}\right)_{3} \mathrm{Ti}\left(\mathrm{O}_{2}\right) \mathrm{F}_{5}+\mathrm{HF} \text {. }
$$

Precipitation obtained on glass is also subjected to $\mathrm{X}$-ray phase analysis. The crystalline phase of anatase is already observed during low-temperature precipitation from the mother liquor. Glass with this coating already produces photocatalytic activity.

As follows from the diagram in Fig. 4, the intensity of reflexes increases with increasing temperature. However, at temperatures above $800{ }^{\circ} \mathrm{C}$, anatase turns into rutile.

The criterion for the presence of a photocatalytic coating of anatase on glass is the interaction of this coating with ultraviolet radiation. To state this fact, spectral studies are performed (Fig. 5).

As a prototype, a quartz glass plate $2 \mathrm{~mm}$ thick is used. The use of quartz glass is dictated by the necessary condition for transparency in the UV range. For uncoated glass (Fig. 5, curve 1), a fairly high transparency is observed in the range $200-400 \mathrm{~nm}$.

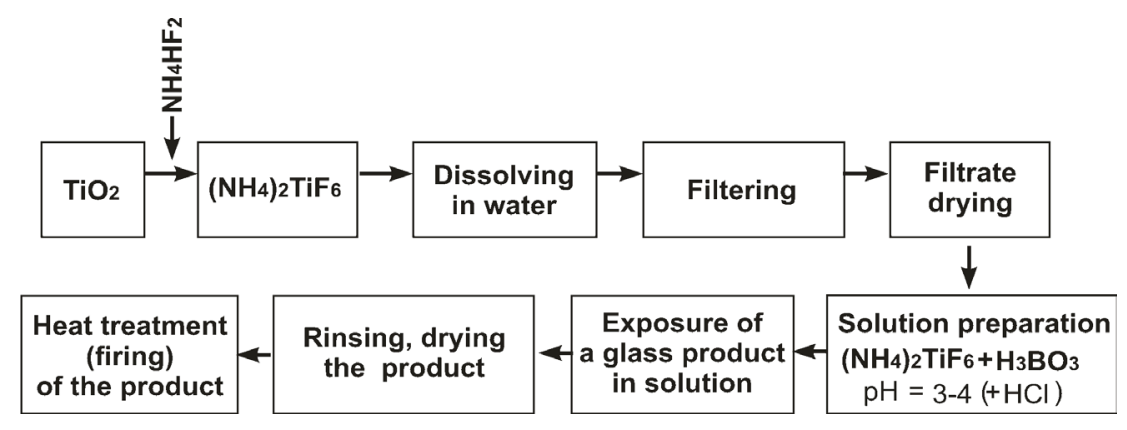

Fig. 2. Scheme of technological operations and transformations 


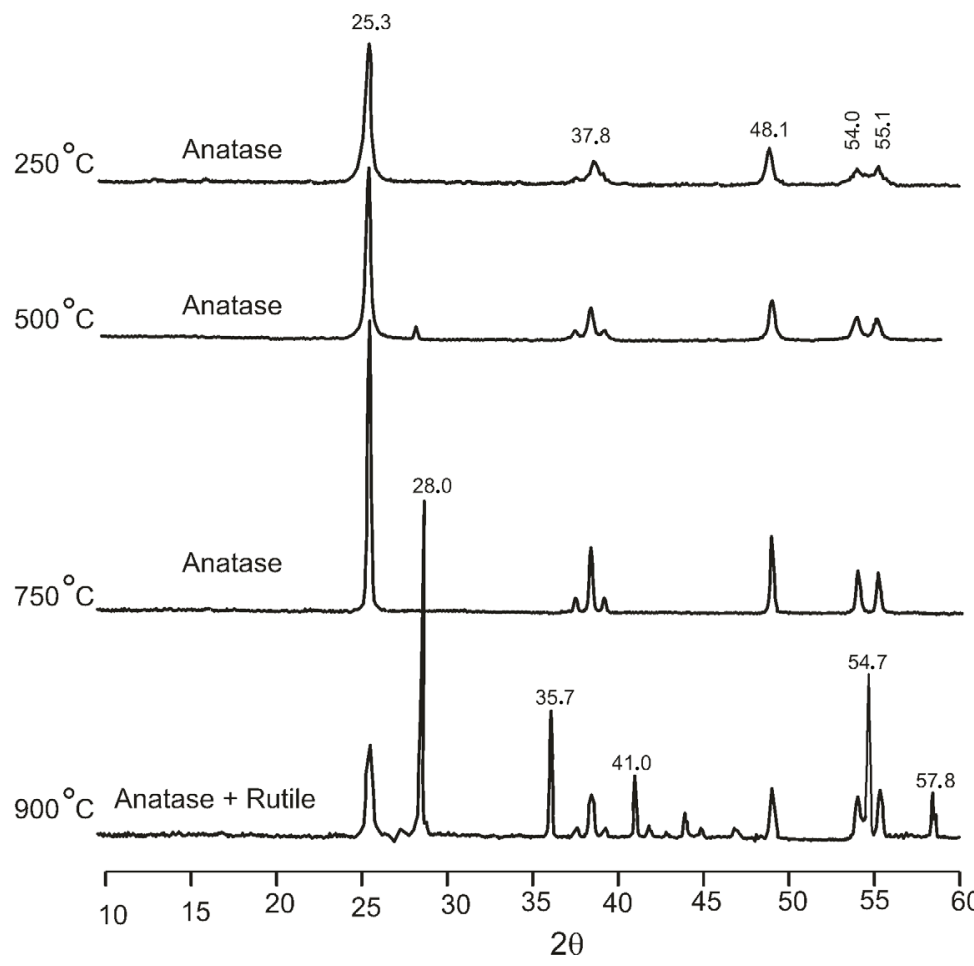

Fig. 4. X-ray phase analysis of the coating at variouspost-treatment temperatures

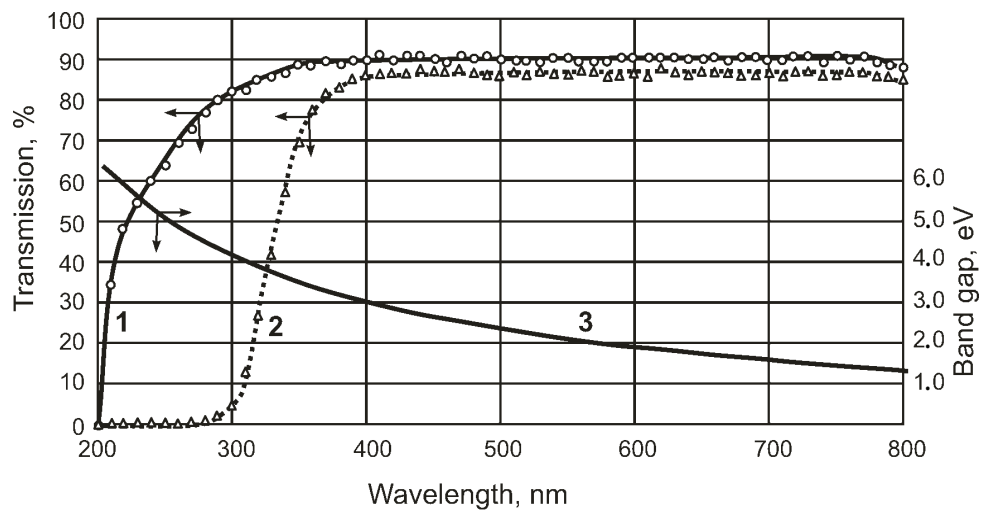

Fig. 5. Spectral studies:

1 - transmission curve of quartz glass without coating; 2 - transmission curve of coated silica glass; 3 - interdependence of the band gap and wavelength

For coated glass (Fig. 5, curve 2), there is a complete absorption of radiation in the range $200-300 \mathrm{~nm}$ and a significant decrease in transparency in the range 300-400 nm. For clarity, the interdependence of the band gap on the wavelength is shown (Fig. 5, curve 3). As follows from Fig. 5, the high transparency of the coated glass is restored after about $380 \mathrm{~nm}$, which corresponds to an anatase gap of $3.2 \mathrm{eV}$.

\section{SWOT analysis of research results}

Strengths.An alternative technology for applying a selfcleaning coating to glass is proposed. At that time, it was known that instead of the expensive precursor $\left(\mathrm{NH}_{4}\right)_{2} \mathrm{TiF}_{6}$, much cheaper reagents were used as precursors in the technological scheme of transformations: $\mathrm{TiO}_{2}$ and $\mathrm{NH}_{4} \mathrm{HF}_{2}$.

The synthesis of $\left(\mathrm{NH}_{4}\right)_{2} \mathrm{TiF}_{6}$, which becomes an intermediate product, is carried out at relatively low temperatures (not more than $200^{\circ} \mathrm{C}$ ) and without the release of toxic fluorinated substances. This complies with the principles of energy conservation and environmental safety of the process.

The yield of the reaction for producing $\left(\mathrm{NH}_{4}\right)_{2} \mathrm{TiF}_{6}$ is quite high (not less than $95 \%$ ). This product is readily soluble in water. The precipitate obtained after filtering its solution and drying is subjected to $\mathrm{x}$-ray phase analysis, which confirmed the presence of this particular product with a possible admixture of oxofluorotitanate, which is not an obstacle to coating the glass.

The photocatalytic coating is applied to glass by immersion of a glass sample in a solution of $\left(\mathrm{NH}_{4}\right)_{2} \mathrm{TiF}_{6}$ and $\mathrm{H}_{3} \mathrm{BO}_{3}$ at room temperature and a holding time of several hours. Nanostructured anatase coatings are formed on the glass. Further heat treatment of the glass samples is advisable. X-ray phase analysis showed an increase in the content of nanostructured anatase to temperatures of about $750{ }^{\circ} \mathrm{C}$. The size of the crystallites calculated by the Scherrer formula is $15-20 \mathrm{~nm}$. At higher temperatures, there is a risk of the conversion of anatase to rutile, which is not desirable.

The presence of the photocatalytic properties of the coating and, as a consequence, the selfcleaning properties of the glass are investigated indirectly: by the spectral method and by measuring the contact angle of water wetting on the glass. A spectral study shows the disappearance of the transparency of quartz glass with this coating in the UV range of $200 \div 400 \mathrm{~nm}$. The contact angle of glass wetting decreased to $2 \div 3^{\circ}$.

Weaknesses. However, the main characteristic, namely, the ability to self-cleanse is not investigated in the work. Since the work speaks of self-cleaning glazing from atmospheric pollutants, such an experiment will require a long time, modeling the effects of various pollutants, various degrees of moisture of the glass, and the like. The authors proceed from the following axiomatic statement: «superhydrophilicity» is a mandatory attribute of the self-cleaning ability of glass.

Opportunities. In recent years, fluoride technologies have begun to be intensively used in various sectors of the chemical industry. They allowto get high purity substances. Ammonium bifluoride $\mathrm{NH}_{4} \mathrm{HF}_{2}$ is used as the main reagent for fluorination. Of relatively great importance is its relatively low cost (5 USD per $1 \mathrm{~kg}$ ). Important is the fact that ammonium bifluoride is a by-product of many fluoride plants. Titanium dioxide is also widely used in industry due to its relatively low cost (8 USD per $1 \mathrm{~kg}$ ), chemical stability, and non-toxicity to living organisms. Given that the estimated market value of $1 \mathrm{~kg}$ of ammonium hexafluorotitanate is $800 \mathrm{USD}$, it is possible to predict the reduction in the cost of applying this coating by several tens of times.

Threats. Self-cleaning glass has an effective function only in conditions of periodic wetting by atmospheric precipitation. Otherwise, for example, indoors, in car tunnels, such glass will require additional periodic maintenance (washing), greatly simplified compared to ordinary glass. 


\section{Conclusions}

1. Instead of the expensive precursor $\left(\mathrm{NH}_{4}\right)_{2} \mathrm{TiF}_{6}$, significantly cheaper reagents $\mathrm{TiO}_{2}$ and $\mathrm{NH}_{4} \mathrm{HF}_{2}$ are proposed as precursors in the technological scheme of transformations. To carry out such synthesis, a laboratory setup is proposed, which is a vertical muffle electric furnace with a fluoroplastic vessel in which the synthesis of $\left(\mathrm{NH}_{4}\right)_{2} \mathrm{TiF}_{6}$ takes place. The temperature is maintained at $170 \pm 10{ }^{\circ} \mathrm{C}$. Processing time 5-6 hours.

2. It is found that the yield of the desired product of the synthesis reaction is at least $95 \%$. As a result of the synthesis, it is precisely $\left(\mathrm{NH}_{4}\right)_{2} \mathrm{TiF}_{6}$ that is formed, which is confirmed by X-ray phase analysis. In addition, ammonium oxofluorotitanate is also likely to form, which is not an obstacle to coating with Anatase.

3. Coated silicate glass from an aqueous solution of $\left(\mathrm{NH}_{4}\right)_{2} \mathrm{TiF}_{6}$ and $\mathrm{H}_{3} \mathrm{BO}_{3}$. It is found that the crystalline phase of anatase forms immediately after precipitation at room temperature. Further heating of the coated glass to temperatures of about $800{ }^{\circ} \mathrm{C}$ is advisable, since the crystalline phase of anatase accumulates. The size of crystalline clusters is estimated by the Scherrer formula at $15 \div 20 \mathrm{~nm}$.

4. It is shown that the ability of the coating to photocatalytic activity is ascertained by spectrophotometric method and measurement of the contact angle. So, in the first case, the complete opacity of the coating in the UV range is detected, and in the second case, the «superhydrophilicity» of the glass is detected. The contact angle with water decreases to $2 \div 3^{\circ}$.

\section{References}

1. Minella, M., Minero, C. (2019). Quantification of the Photocatalytic Self-Cleaning Ability of Non-Transparent Materials. Materials, 12 (3), 508. doi: http://doi.org/10.3390/ma12030508

2. Midtdal, K., Jelle, B. P. (2013). Self-cleaning glazing products: A state-of-the-art review and future research pathways. Solar Energy Materials and Solar Cells, 109, 126-141. doi: http:// doi.org/10.1016/j.solmat.2012.09.034

3. Schneider, J., Matsuoka, M., Takeuchi, M., Zhang, J., Horiuchi, Y., Anpo, M., Bahnemann, D. W. (2014). Understanding $\mathrm{TiO}_{2}$ Photocatalysis: Mechanisms and Materials. Chemical Reviewes, 114 (19), 9919-9986. doi: http://doi.org/10.1021/cr5001892

4. Landmann, M., Rauls, E., Schmidt, W. G. (2012). The electronic structure and optical response of rutile, anatase and brookite $\mathrm{TiO}_{2}$. Journal of Physics: Condensed Matter, 24 (19), 195503. doi: http://doi.org/10.1088/0953-8984/24/19/195503

5. Karunagaran, B., Uthirakumar, P., Chung, S. J., Velumani, S., Suh, E.-K. (2007). $\mathrm{TiO}_{2}$ thin film gas sensor for monitoring ammonia. Materials Characterization, 58 (8-9), 680-684. doi: http:// doi.org/10.1016/j.matchar.2006.11.007

6. Pan, J., Leygraf, C., Thierry, D., Ektessabi, A. M. (1997). Corrosion resistance for biomaterial applications of $\mathrm{TiO}_{2}$ films deposited on titanium and stainless steel by ion-beam-assisted sputtering. Journal of Biomedical Materials Research, 35 (3), 309-318. doi: http:// doi.org/10.1002/(sici)1097-4636(19970605)35:3<309::aid-jbm5> 3.0.co;2-1

7. Wu, J.-J., Yu, C.-C. (2004). Aligned TiO2Nanorods and Nanowalls. The Journal of Physical Chemistry B, 108 (11), 3377-3379. doi: http://doi.org/10.1021/jp0361935

8. Wu, J.-M., Shih, H. C., Wu, W.-T., Tseng, Y.-K., Chen, I.-C (2005). Thermal evaporation growth and the luminescence property of $\mathrm{TiO}_{2}$ nanowires. Journal of Crystal Growth, 281 (2-4), 384-390. doi: http://doi.org/10.1016/j.jcrysgro.2005.04.018

9. Chen, X., Mao, S. S. (2007). Titanium Dioxide Nanomaterials: Synthesis, Properties, Modifications, and Applications. Chemical Reviewes, 107 (7), 2891-2959. doi: http://doi.org/10.1021/cr0500535

10. Chiarello, G. L., Selli, E., Forni, L. (2008). Photocatalytic hydrogen production over flame spray pyrolysis-synthesised $\mathrm{TiO}_{2}$ and $\mathrm{Au} / \mathrm{TiO}_{2}$. Applied Catalysis B: Environmental, 84 (1-2), 332-339. doi: http://doi.org/10.1016/j.apcatb.2008.04.012
11. Šćepanović, M., Dohčević-Mitrović, Z., Hinić, I., Grujić-Brojčin, M. Stanišić, G., Popović, Z. V. (2005). Photoluminescence of LaserSynthesized Anatase Titanium Dioxide Nanopowders. Materials Science Forum, 494, 265-270. doi: http://doi.org/10.4028/www. scientific.net/msf.494.265

12. Seifried, S., Winterer, M., Hahn, H. (2000). Nanocrystalline Titania Films and Particles by Chemical Vapor Synthesis. Chemical Vapor Deposition, 6 (5), 239-244. doi: http://doi.org/ 10.1002/1521-3862(200010)6:5<239::aid-cvde239>3.3.co;2-h

13. Wu, J.-M., Shih, H. C., Wu, W.-T., Tseng, Y.-K., Chen, I.-C. (2005). Thermal evaporation growth and the luminescence property of $\mathrm{TiO}_{2}$ nanowires. Journal of Crystal Growth, 281 (2-4), 384-390. doi: http://doi.org/10.1016/j.jcrysgro.2005.04.018

14. Cheng, H., Ma, J., Zhao, Z., Qi, L. (1995). Hydrothermal Preparation of Uniform Nanosize Rutile and Anatase Particles. Chemistry of Materials, 7 (4), 663-671. doi: http:// doi.org/10.1021/cm00052a010

15. Li, X.-L., Peng, Q., Yi, J.-X., Wang, X., Li, Y. (2006). Near Monodisperse TiO2 Nanoparticles and Nanorods. Chemistry A European Journal, 12 (8), 2383-2391. doi: http://doi.org/ 10.1002 /chem. 200500893

16. Estekhraji, S. A. Z., Amiri, S. (2017). Sol-gel preparation and characterization of antibacterial and self-cleaning hybrid nanocomposite coatings. Journal of Coatings Technology and Research, 14 (6), 1335-1343. doi: http://doi.org/10.1007/s11998-0179932-7

17. Maver, K., Štangar, U. L., Černigoj, U., Gross, S., Cerc Korošec, R. (2009). Low-temperature synthesis and characterization of $\mathrm{TiO}_{2}$ and $\mathrm{TiO}_{2}-\mathrm{ZrO}_{2}$ photocatalytically active thin films. Photochemical \& Photobiological Sciences, 8 (5), 657-662. doi: http:// doi.org/10.1039/b817475j

18. Han, S., Choi, S.-H., Kim, S.-S., Cho, M., Jang, B., Kim, D.-Y et. al. (2005). Low-Temperature Synthesis of Highly Crystalline $\mathrm{TiO}_{2}$ Nanocrystals and their Application to Photocatalysis. Small, 1 (8-9), 812-816. doi: http://doi.org/10.1002/smll.200400142

19. Jelle, B. P., Hynd, A., Gustavsen, A., Arasteh, D., Goudey, H., Hart, R. (2012). Fenestration of today and tomorrow: A stateof-the-art review and future research opportunities. Solar Energy Materials and Solar Cells, 96, 1-28. doi: http://doi.org/ 10.1016/j.solmat.2011.08.010

20. Gläser, H. J., Ulrich, S. (2013). Condensation on the outdoor surface of window glazing - Calculation methods, key parameters and prevention with low-emissivity coatings. Thin Solid Films, 532, 127-131. doi: http://doi.org/10.1016/j.tsf.2012.12.110

21. Deki, S., Aoi, Y., Hiroi, O., Kajinami, A. (1996). Titanium (IV) Oxide Thin Films Prepared from Aqueous Solution. Chemistry Letters, 25 (6), 433-434. doi: http://doi.org/10.1246/cl.1996.433

22. Deki, S., Aoi, Y., Asaoka, Y., Kajinami, A., Mizuhata, M. (1997) Monitoring the growth of titanium oxide thin films by the liquid-phase deposition method with a quartz crystal microbalance. Journal of Materials Chemistry, 7 (5), 733-736. doi: http:// doi.org/10.1039/a607466i

23. Gutiérrez-Tauste, D., Domènech, X., Angeles Hernández-Fenollosa, M., Ayllón, J. A. (2006). Alternative fluoride scavengers to produce TiO2films by the liquid phase deposition (LPD) technique. J. Mater. Chem., 16 (23), 2249-2255. doi: http:// doi.org $/ 10.1039 / \mathrm{b} 515367 \mathrm{k}$

24. Masuda, Y., Sugiyama, T., Seo, W. S., Koumoto, K. (2003) Deposition Mechanism of Anatase TiO2on Self-Assembled Monolayers from an Aqueous Solution. Chemistry of Materials, 15 (12), 2469-2476. doi: http://doi.org/10.1021/cm030255m

25. Niesen, T. P., De Guire, M. R. (2002). Review: deposition of ceramic thin films at low temperatures from aqueous solutions Solid State Ionics, 151, 61-68. doi: http://doi.org/10.1016/ s0167-2738(02)00604-5

Plemyannikov Mykola, PhD, Professor, Department of Chemical Technology of Ceramics and Glass, National Technical University of Ukraine «Igor Sikorsky Kyiv Polytechnic Institute», Ukraine, e-mail: plemja46@gmail.com, ORCID: http://orcid.org/0000-00034756-3540

Kornilozych Borys, Doctor of Chemical Sciences, Professor, Corresponding Member of NAS Ukraine, Head of Department of Chemical Technology of Ceramics and Glass, National Technical University of Ukraine «Igor Sikorsky Kyiv Polytechnic Institute», Ukraine, e-mail: b_kornilovych@kpi.ua, ORCID: http://orcid.org/0000-00026393-6880 